\title{
IMPLEMENTING INTERACTIVE METHODS FOR DEVELOPING STUDENTS' INTERCULTURAL COMMUNICATIVE COMPETENCE
}

\author{
Feruza Ibrohimjonovna Alimjanova
}

Lecturer Fergana state university

\section{ABSTRACT}

It is known that any language teaching technology is based on new principles of education, but at the same time should serve for developing students' intercultural communicative competence in the educational process. One of the main tasks of pedagogy is to improve the quality of education, increase the intellectual activity of students, the formation of the speech culture, and the introduction of new methods in the classroom. The subject and object of the educational process are a teacher and a student in effective pedagogical technology.

KEYWORDS:- Development of the student, create a creative, intercultural communicative, Pedagogical technologies.

\section{INTRODUCTION}

Therefore, the cooperation and interaction of these two individuals should be based on the most modern and national requirements. In order to achieve high results, the educational process, the teacher, the requirements of the educational process, the principles and ways of organization and management of education, methods of mental and physical development of the student, cooperation with him, directing him to study and learning, proper organization of personal activities, to communicate with them, to solve problems and disagreements, to create a creative, business environment in the audience, the learner must be equipped with valid and reliable methods of assessment of student's performance.

One of the most important requirements for the organization of modern education today is the formation of students' intercultural communicative competence. The formation of necessary skills and subskills in a particular filed of science, monitoring the learners' activities, assessment of the level of competence requires high pedagogical skills from the teacher.

\section{Materials AND MEthods}

In general, the following researchers have studied the problems of teaching a foreign 
language for intercultural communication, the use of interactive methods for developing intercultural communication: (1) theory of interpersonal communication (A.A.Bodalev, V.A.Dobrovich); (2) the theory of intercultural communication (A.Viirlacher, E.M.Vereshchagen, V.G.Kostomarov, O.V.Lesher, G.Noyner); (3) the concept of "Dialogue of Cultures" (MM Bakhtin, VS Bibler, L.S.Vigotsky, M.K.Petrov, M.A.Sokolova). (4) Teaching intercultural communication by teaching types of speech activities and language material in foreign language teaching (J..J.Jalolov, TKSattorov, M.Jusupov, J.Yakubov, H.R.Rakhimov, M.S.Dadahojaeva et al.); (5) preparing future foreign language teachers for intercultural communication (V.N.Barishnikov, N.D.Galskova, F.Isaeva, R.P.Milrud, G.D.Maltseva, E.I.Passov, V.V.Safonova, I.I.Khaleeva, A.I.Shcherbakova, L.N.Yakovleva). Also published monographs, dissertations, manuals and developments, scientific and methodological articles and abstracts.

\section{Result AND Discussion}

The following samples of information were used in the lesson to check the students' speech level in a foreign language: (1) the text in the course book is read in advance and prepared for retelling; (2) pre-preparation is given to tell the impression of the educational film seen; (3) students are given a newspaper article in advance and prepared to narrate its content. The methods and approaches covered in foreign language teaching methodology are many and varied. The issue of scientific study of the reasons for the development of foreign language teaching methods has attracted many researchers. [1] In general, the foreign language teaching methods historically can be divided into the following groups: 1) the grammar-translation method; 2) direct (natural) methods and their modern forms; 3) eclectic method; 4) bilingual method; 5) communicative approach with learner centered education.

The methods of teaching foreign languages means the sum of the activities of teachers and students in reaching the overall educational goals in foreign language education. At the same time, specific approaches to foreign language teaching have been found to be acceptable in different times and places. I.L.Bim divides approaches to foreign language teaching into four groups: (1) behaviorist approach (building skills and competencies by mechanically repeating language material), (2) inductiveconscious approach (following examples to understand rules), (3) a systematic approach (teaching morphology and syntax), (4) a cognitive approach [2].

The use of interactive methods in developing students' intercultural communication is very effective. The interactive method is understood as the interaction between a teacher and a learner. Activity does not arise spontaneously. The activation of learners depends on the choice of language material to be mastered, with a focus on its quality in presentation. Increasing student activity allows:

- ensuring regular and active participation of students in the lessons;

- to establish a conscious, positive relationship between teacher and student;

- to develop the student's ability to work independently with various sources of information;

- acquisition of positive socially important qualities;

Active learning is the result of regular, sequential, systematic assignments, the creation of problematic situations. Activity arises on the 
basis of consciousness. Increasing the learning activity of students in the process of learning a foreign language depends on teaching them to focus on the object of study, logical thinking, which is the product of mental activity. Pedagogical technologies aimed at increasing the effectiveness of students' cognitive activity, have a positive effect on the high level of conscious activity and the increase in conscious need. These include didactic games, task-based learning, and collaborative learning technologies.

The following types of interactive methods are used in the education system: "Brainstorming", "Dialectical method", "Problem interpretation", "Vein Diagram", "Cluster" methods have been shown to be highly effective in experimental work [3].

The following experiment will reflect on the nature of the interactive methods used in the experiments and their application in the classroom.

Brainstorming method teaches students to think independently, ensuring activity. The purpose of the method is to help students think independently, discuss a specific topic, get a large number of options in a short period, and determine the knowledge of students acquired through problem situations. The value of the method is that it unites the groups.

The dialectical method can be introduced as one of the forms of logical thinking in the educational process, which helps students to create conditions for autonomous learning and expression of ideas independently on the chosen problems. It also develops students' ability to distinguish between good and evil. In this way, the situation can be discussed in groups by interpreting the situation.

Students will be asked to describe a picture that is written or a problem situation in the method of problem interpretation. At the same time, the problems should consist of pictures and problematic situations related to the formation of students' intercultural communicative competence.

In order to improve dialogue speech in foreign language classes, the following communicative exercises are recommended in addition to the exercises provided in the current textbooks:

1. Analyze the content of a given dialogue. In doing this exercise, students first read the dialogue, then the teacher asks the students questions. The focus is on understanding the content of the conversation. To analyze the content of dialogue, attention is paid to the situation in which the conversation took place. The teacher instructs the students that a new student has arrived in the classroom and to have a conversation with him or her.

2. Read the dialogue and develop it.

3. Create a dialogue based on pictures depicting different situations

This can be suggested by commenting on the following situations.

1. Work with a new word.

2. Describe the picture in writing.

3. Conduct role-play games. Role-play games can be used to develop speech culture and prepare for verbal and nonverbal communication. Visual aids are widely used in role-play games. Students feel like representatives of the country where their language is being studied during role-play games. Role-play games are prepared in pairs or groups. Conditions are created for students to communicate freely.

In this process, it is advisable to stage more problematic, life situations. Role-play games can be selected based on the practical, educational, pedagogical, and developmental goals of education. It is well known that students can be 
shy, timid, and violent according to their temperament. For insecure students, roles were given that had little word, pantomime. This allows students to feel confident among their peers. For example, the student was asked to tell what to do in the morning (washing-up, brushing teeth, combing, and dressing). Students' behavior showed with the help of actions.

5. Discussion is one of the interactive methods, which helps students to form new knowledge about the culture of the country where the language is studied, draw conclusions, develop their own opinions, prove it and develop communication skills.

The teacher initiates the discussion, but does not participate. He acts as a judge. Potential students were given more complex roles.

You are assigned to take English students.

You take German students on a trip and try to answer their questions.

6. Observe and analyze the others' speech. Before the exercise, a tape recorder and a video recorder are prepared. Various sounds recorded on a tape (conversation, radio broadcast, TV record) are presented to students during the lesson.

7. Conversation on problematic topics. Taskbased learning encourages students to explore, think, and think critically. The approximate names of the speaking topics were chosen according to the curriculum and formed the basis of the lessons during the experiment.

Excursion travel lessons were also widely used in the study. The main purpose of this lesson is to increase the cognitive activity of students in the process of communication.

The use of a travel lesson on "In front of the world map" during the lessons will arouse students' interest in the country where the language is being studied.

\section{Conclusion}

In conclusion, the use of interactive methods increases the level of intercultural communicative competence of students. In the context of globalization of education, the technological structure aimed at improving the intercultural communicative competence of students and will be improved on the basis of methods, forms, means of developing intercultural competence by defining stages of mutual integration of cultural elements (political, economic, legal, ethical, ecological, aesthetic).

In the context of globalization of education, the process of organizing educational work in developing the students' intercultural communicative competence is improved on the basis of spiritual and cultural special programs and pedagogical tools (collective holidays, competitions, meetings, performances, and reading nights).

\section{REFERENCES}

1. Ahmadjonova E.T., \&Bakhromovich, S.I. Pedagogical Analysis of CulturalEducational Institutions' Actions In Youth Education (On The Example of Museum Activities) // The American Journal of Social Science and Education Innovations, 2(08), - P. 576-582. 2020.

2. Bakhromov S.I. Effects of Objective and Subjective Factors to Develop Intellectual Culture of Youth // Canadian Social Science, 16(2), - P. 55-59. 2020.

3. Бим И.Л. Профильное обучение иностранным языкам на старшей ступени общеобразовательной школы. $-2007$. 
CURRENT RESEARCH JOURNAL OF PEDAGOGICS 2(5): 20-24, May 2021

DOI: https://doi.org/10.37547/pedagogics-crjp-02-05-04

ISSN 2767-3278

(C)2021 Master Journals

Crossref dof 81 Google

Accepted 15 $5^{\text {th }}$ May, $2021 \&$ Published 20th May, 2021

4. Mirzarahimov B.H. The Tasks Of Tourism In Aesthetic Education: The Harmony of Historicity And Modernity // The American Journal of Social Science and Education Innovations,2(09), - P. 652-658. 2020.

5. Mirzarakhimov B. Tourism is a modern means of aesthetic education// Сборник статей. 2020.

6. Туракулов Э. Педагогик технологиялар ва махорат // (Магистрлар учун). 2006. 